\title{
Al-Qardh dan Al-Qardhul Hasan sebagai Wujud Pelaksanaan Tanggung Jawab Sosial Perbankan Syariah
}

\author{
Muhammad Imam Purwadi \\ Fakultas Hukum Universitas Mataram \\ Jl. Majapahit No. 62 Kota Mataram NTB \\ mampur@yahoo.co.id
}

\begin{abstract}
The problems discussed in this research are: first, how the responsibility of sharia banking in Indonesia is, and second, the how the development and implementation of legal provision of al-qardh andalqardhul hasanproducts are as the realization of social responsibility of sharia banking to create the social welfare in PT Bank Muamalat Indonesia Tbk. This research is a qualitative study using normative juridical and empirical juridical approaches. The result of the research concludes that: first, corporatesocial responsibilityof sharia banking is defined as an instrument to enhance the work performance and service for the society. The implementation of CSR program varies in forms of assistances for education, health, poverty alleviation, social, religion, infrastructure, and environment, as well as through financing products. Second, in its implementation, there is not a specific provision regulating the implementation of al-qardhandal-qardhul hasanas CSR in sharia banking. PT Bank Muamalat Tbk has not yet formulated the application and implementation of al-qardhandal-qardhul hasanprinciples to realize the social welfare.
\end{abstract}

Key words : Qardhul Hasan, CSR, sharia banking

\begin{abstract}
Abstrak
Adapun permasalahan dalam penelitian ini, pertama: bagaimana pertanggungjawaban perbankan syariah di Indonesia. Kedua, perkembangan dan pelaksanaan ketentuan hukum produk al-qardh dan al-qardhul hasan sebagai wujud tanggung jawab sosial perbankan syariah dalam upaya mewujudkan kesejahteraan sosial pada PT Bank Muamalat Indonesia Tbk. Penelitian ini merupakan penelitian kualitatif yang menggunakan pendekatan yuridis normatif dan yuridis empiris. Hasil penelitian menyimpulkan: pertama, tanggung jawab sosial perusahaan (corporate social responsibility) perbankan syariah dimaknai sebagai instrumen untuk meningkatkan kinerja dan pelayanan pada masyarakat. Penerapan program CSR tersebar dalam bentuk bantuan pendidikan, kesehatan, kemiskinan, sosial, agama, infrastruktur, dan lingkungan hidup serta melalui produk pembiayaan. Kedua, dalam pelaksanaannya belum ada regulasi spesifik (khusus) yang mengatur pelaksanaan al-qardh dan alqardhul hasan sebagai CSR pada perbankan syariah. PT Bank Muamalat Tbk belum merumuskan aplikasi dan implementasi prinsip al-qardh dan al-qardhul hasan dalam upaya mewujudkan kesejahteraan sosial.
\end{abstract}

Kata kunci: Qardhul hasan, CSR, perbankan syariah 


\section{Pendahuluan}

Perkembangan ekonomi Islam di Indonesia dalam beberapa tahun terakhir ini, baik pada tataran teoritis-konseptual, sebagai wacana akademik, maupun pada tataran praktis, khususnya di lembaga keuangan bank dan lembaga keuangan nonbank, sangat pesat. Kehadiran Hukum Ekonomi Islam atau sering disebut istilah "ekonomi syariah", merupakan kebutuhan masyarakat luas (Islam) oleh karena adanya manfaat dalam mensejahterakan masyarakat. Kedudukan ekonomi syariah sama sekali tidak bertentangan dengan dasar falsafah Negara Indonesia, yaitu Pancasila terutama sila pertama dan kelima.

Ekonomi syariah sangat bersesuaian dengan UUD 1945 sebagai konstitusi negara Indonesia, yang dalam pembukaannya disebutkan “...dengan mewujudkan suatu keadilan sosial bagi seluruh rakyat Indonesia." Salah satu kegiatan ekonomi syariah adalah Bank Syariah atau Perbankan Syariah yang pelaksanaannya berdasarkan pada prinsip-prinsip syariah. ${ }^{1}$

Dalam Undang-Undang Nomor 21 Tahun 2008 tentang Perbankan Syariah, ditegaskan bahwa Bank Syariah adalah Bank yang menjalankan kegiatan usahanya berdasarkan prinsip syariah dan menurut jenisnya terdiri atas Bank Umum Syariah dan Bank Pembiayaan Rakyat Syariah. ${ }^{2}$

Sejak Bank Muamalat Indonesia (BMI) berdiri dan mulai beroperasi pada 1 Mei 1992, pertumbuhan perbankan syariah terus meningkat. Dari satu Bank Umum Syariah (BUS) dan 78 Bank Pembiayaan Rakyat Syariah (BPRS) pada 1998, menjadi tiga Bank Umum Syariah (BUS) dan 19 bank umum yang membuka Unit Usaha Syariah (BUUS) dengan 154 kantor cabang, serta 92 Bank Pembiayaan Rakyat Syariah (BPRS) pada akhir tahun 2005. Perkembangan jaringan kantor perbankan syariah, pada tahun 2005 baru berjumlah 550 kantor, namun pada akhir 2010 jumlah tersebut menjadi 1668 kantor. ${ }^{3}$ Penyebaran jaringan kantor perbankan syariah telah menjangkau masyarakat di 33 Propinsi dan di kabupaten/kota. Sementara itu, jumlah Bank Umum Syariah (BUS) sampai akhir Oktober 2008 baru berjumlah 5 Bank Umum Syariah, maka pada akhir 2010, total Bank Umum Syariah (BUS) telah menjadi 11 buah. ${ }^{4}$

\footnotetext{
${ }^{1}$ Sutan Remy Syahdeini, "Perbankan Islam dan Kedudukannya dalam Tata Hukum Perbankan Indonesia”, PT Kreatama, Jakarta, 2005, hlm. 5-6.

${ }^{2}$ Pasal 1 angka 7 Undang-Undang Nomor 21 Tahun 2008 tentang Perbankan Syariah.

${ }^{3}$ Bank Indonesia, Laporan BI: Statistik Perbankan Syariah November 2010, Bank Indonesia, Jakarta, hlm.1.

${ }^{4}$ Agustianto, Evaluasi Bank Syariah 2008 dan Outlook 2009 (bagian 1), sebagaimana dikutip oleh Dadan Muttaqien, "Politik Hukum Pemerintah RI terhadap Perbakan Syariah Pasca disahkannya UU No. 21 Tahun 2008 tentang Perbankan
} 
Salah satu produk Perbankan Syariah yang menjadi kajian dalam penelitian untuk ini adalah produk sosial perbankan syariah, yakni al-qardh dan al-qardhul hasan. ${ }^{5}$ Al-qardh dan al-qardhul hasan adalah suatu sistem yang berkaitan dengan segala bentuk pinjaman tanpa imbalan yang berasaskan pada hukum al-qardh. ${ }^{6}$ Istilah alqardh, menurut bahasa Arab berarti pinjaman ${ }^{7}$, yaitu meminjamkan sesuatu kepada orang lain, di mana pihak yang dipinjami sebenarnya tidak ada kewajiban mengembalikan.

Para ulama fikih, sepakat bahwa al-qardh boleh dilakukan, atas dasar bahwa tabiat manusia tidak bisa hidup tanpa pertolongan dan bantuan saudaranya. Tidak ada seorang pun yang memiliki segala sesuatu yang dibutuhkannya untuk kehidupan. Oleh karena itu, pinjam meminjam sudah menjadi satu bagian dari kehidupan di dunia, dan Islam adalah agama yang sangat memperhatikan segenap kebutuhan umatnya. ${ }^{8}$

Dalam konteks ini, program al-qardh dan al-qardhul hasan merupakan misi sosial perbankan syariah. Misi sosial ini sebagai upaya tanggung jawab sosial perbankan syariah yang bertujuan meningkatkan citra bank, meningkatkan loyalitas masyarakat terhadap bank syariah, dan menumbuhkan pemberdayaan masyarakat. Hal ini, senada dengan perspektif ajaran Agama Islam, bahwa aktivitas finansial dan perbankan dalam dunia modern seperti sekarang ini mengandung dua prinsip, yaitu prinsip al-ta'awun ${ }^{9}$

Syariah”, makalah Seminar Nasional “Sosialisasi UU No. 21 Tahun 2008 tentang Perbankan Syariah”, FIAI UII Yogyakarta, 7 Pebruari 2009, hlm. 4-5.

${ }^{5}$ Al-Qardhul Hasan dalam aplikasi perbankan syariah sering disebut dengan Akad al-Qardh, yaitu perjanjian pembiayaan berupa transaksi pinjam meminjam dana tanpa imbalan dengan kewajiban pihak peminjam mengembalikan pokok pinjaman secara sekaligus atau cicilan dalam jangka waktu tertentu, Bank Indonesia: BI Statistik Perbankan Syariah November 2010, Op. Cit., hlm. ix.

${ }^{6}$ Lihat, Osman Sabran, Urus Niaga al-Qardh al Hasan dalam Pinjaman Tanpa Riba, University Teknologi Malaysia, Kuala Lumpur, 2001, hlm. 1.

${ }^{7}$ Istilah ini ditegaskan dalam al-Qur'an surat al-Hadiid ayat 11, yang artinya kurang lebih sebagai berikut: "Siapakah yang mau meminjamkan kepada Allah pinjaman yang baik, maka Allah akan melipatgandakan (balasan) pinjaman itu untuknya, dan dia akan memperoleh pahala yang banyak."

${ }^{8}$ Abdul Azis Dahlan, et.al., Op. Cit., hal. 1197. Pinjam meminjam dalam konteks Qardhul Hasan sebaiknya dibedakan dengan konsep pinjam meminjam dalam makna al-Ariyah. Pinjam meminjam (al-ariyah) adalah transaksi atas manfaat suatu barang tanpa imbalan. Secara sederhana, al-ariyah adalah menyerahkan suatu wujud barang untuk dimanfaatkan tanpa imbalan. Ta'rif di atas, apabila barang yang dimanfaatkan itu diwujudkan dengan imbalan tertentu, maka dinamakan sewa menyewa atau al-ijarah, bukan al-ariyah. Karena itu, dalam al-ariyah yang ditransaksikan adalah barang yang manfaatnya dapat dikuasai oleh peminjam (musta'ir) dengan cuma-cuma, sedangkan wujud bendanya tetap menjadi milik yang meminjamkan (mu'ir) yang harus dikembalikan. Apabila, barang yang dikembalikan itu bukan wujud barangnya, tetapi nilai atau harganya atau dalam bentuk lain, tidak dinamakan pinjam-meminjam, tetapi utang piutang. Lihat, Hedi Suhendi, Fikih Muamalat, Jakarta, RajaGrafindo Persada, 2002, hlm. 34-36, Ahmad Mulyadi, Fiqih, Penerbit Titian Ilmu, Bandung, 2006, hlm. 45, dan Ma’ruf Abdul Jalil, Al-Wajiz, Pustaka As-Sunah, Jakarta, 2006, hlm. 37.

${ }^{9}$ Salah satu prinsip penting dalam Islam yang banyak disebutkan dalam Al Qur'an dan As Sunnah adalah prinsip At Ta'awn 'ala al-Birri wa at-Taqwa (saling membantu di atas kebaikan dan ketaqwaan kepada Allah s.w.t). Prinsip al-ta'awun dimaksudkan sebagai sikap saling membantu dan saling bekerjasama di antara anggota masyarakat untuk 
dan prinsip menghindari al-iktinaz. ${ }^{10}$ Pengelolaan al-qardh dan al-gardhul hasan belum menjadi prioritas dalam pengembangan perbankan syariah menjadi suatu hal yang menarik untuk diteliti, terutama pada aspek mengapa perbankan syariah mengabaikan misi sosialnya.

Persoalan yang mendasar dalam aplikasi perbankan syariah adalah apakah al-qardh dan al-qardhul hasan dapat menjadi sebuah pertanggung jawaban sosial dari perbankan syariah? Dalam Undang-Undang Nomor 21 Tahun 2008 tentang Perbankan Syariah, Pasal 2, 3, dan 4, yang menjelaskan bahwa perbankan syariah dalam menjalankan fungsinya bertujuan untuk menunjang pelaksanaan pembangunan nasional dalam rangka meningkatkan keadilan, kebersamaan dan pemerataan kesejahteraan rakyat. Sebagai salah satu implementasi tujuan tersebut perbankan syariah dapat menjalankan fungsi sosialnya dalam bentuk baitul mal, yaitu menerima dana yang berasal dari zakat, infak, sedekah, atau dana sosial lainnya dan menyalurkannya kepada masyarakat. ${ }^{11}$

Berkaitan dengan pentingnya program al-qardhul hasan sebagai CSR, karena program pembiayaan al-gardhul hasan merupakan aktivitas perbankan yang dapat memberikan respon positif pada upaya pemberdayaan masyarakat. Dalam konteks ini, program al-qardhul hasan memiliki banyak kesamaan dengan program CSR sebagai aktualisasi pertanggungjawaban sosial perusahaan pada masyarakat. Program al-qardhul hasan berarti juga mewujudkan tanggung jawab sosial perbankan Syariah dalam membantu masyarakat dalam mengembangkan usahanya. Dengan model aplikasi program al-qardhul hasan dapat diterapkan CSR dengan modifikasi dan

kebaikan, sebagaimana dinyatakan dalam Q.S. al-Maidah ayat 2, yang artinya kurang lebih sebagai berikut: "Hai orangorang yang beriman, ... dan tolong-menolonglah kamu dalam (mengerjakan) kebajikan dan taqwa, dan jangan tolongmenolong dalam berbuat dosa dan pelanggaran. Dan bertaqwalah kamu kepada Allah, sesungguhnya Allah amat berat siksa-Nya”. Lihat, Ma'ruf Abdullah, Hukum Perbankan dan Perkembangan Bank Syariah di Indonesia, Antasari Pers, Banjarmasin, 2006, hlm. 34.

${ }^{10}$ Prinsip menghindari al-iktinaz adalah menahan uang (dana) dengan membiarkannya menganggur tanpa diproduktifkan dalam suatu transaksi yang bermanfaat bagi masyarakat umum, sebagaimana dinyatakan dalam Q.S. an-Nisaa' ayat 29, yang artinya kurang lebih sebagai berikut:"29. Hai orang-orang yang beriman, janganlah kamu saling memakan harta sesamamu dengan jalan yang batil, kecuali dengan jalan perniagaan yang berlaku dengan suka samasuka di antara kamu. ...", Ibid.

${ }^{11}$ UU Nomor 21 Tahun 2008 tentang Perbankan Syariah, Pasal 2 berbunyi: Perbankan Syariah dalam melakukan kegiatan usahanya berasaskan prinsip syariah, demokrasi ekonomi, dan prinsip kehati-hatian. Pasal 3 berbunyi: Perbankan Syariah bertujuan menunjang pelaksanaan pembangunan nasional dalam rangka meningkatkan keadilan, kebersamaan, dan pemerataan kesejahteraan rakyat. Pasal 4 berbunyi: 1) Bank Syariah dan UUS wajib menjalankan fungsi menghimpun dan menyalurkan dana masyarakat; 2) Bank Syariah dan UUS dapat menjalankan fungsi sosial dalam bentuk lembaga baitul mal, yaitu menerima dana yang berasal dari zakat, infak, sedekah, hibah, atau dana sosial lainnya dan menyalurkannya kepada organisasi pengelola zakat; 3) Bank Syariah dan UUS dapat menghimpun dana sosial yang berasal dari wakaf uang dan menyalurkannya kepada pengelola wakaf (na:iri) sesuai dengan kehendak pemberi wakaf (wakif), 4) Pelaksanaan fungsi sosial sebagaimana dimaksud pada ayat (2) dan (3) sesuai dengan ketentuan peraturan perundang-undangan. 
inovasi tertentu, menjadi salah satu ciri pembeda perbankan syariah dengan perbankan konvensional, sehingga menjadikan program al-qardhul hasan dapat diterima oleh masyarakat. Hal ini, sesuai dengan rumusan akad al-qardhul hasan bahwa perjanjian pembiayaan ini dilandasi oleh saling percaya, semangat ukhuwah islamiyah, dan rasa tanggung jawab sosial (social responsibility). ${ }^{12}$

\section{Rumusan Masalah}

Adapun permasalahan dalam penelitian ini, yaitu: pertama, bagaimana Pertanggungjawaban Sosial Perusahaan (Corporate Social Responsibility) Perbankan Syariah di Indonesia? Kedua, bagaimana perkembangan dan pelaksanaan ketentuan hukum produk al-qardh dan al-qardhul hasan sebagai wujud tanggung jawab sosial perbankan syariah dalam upaya mewujudkan kesejahteraan sosial pada PT Bank Muamalat Indonesia Tbk?

\section{Tujuan Penelitian}

Penelitian ini bertujuan untuk: pertama, mengetahui tanggung jawab sosial perusahaan Perbankan Syariah di Indonesia. Kedua, untuk mengetahui perkembangan dan pelaksanaan ketentuan hukum produk al-qardh dan al-qardhul hasan sebagai wujud tanggung jawab sosial perbankan syariah dalam upaya mewujudkan kesejahteraan sosial pada PT Bank Muamalat Indonesia Tbk.

\section{Metode Penelitian}

Penelitian ini merupakan penelitian kualitatif yang menggunakan pendekatan yuridis normatif dan yuridis empiris. Fokus penelitian akan dilakukan pembatasan dalam lingkup apa dan bagaimana al-qardh dan al-qardhul hasan dalam kaitannya dengan upaya Perbankan Syariah memberdayakan ekonomi masyarakat sebagai wujud pertanggung jawaban sosial (corporate social responsibility). Penelitian dilakukan berdasarkan studi pada PT Bank Mu'amalat Indonesia Tbk. Untuk memperoleh bahan dan data yang berhubungan dengan tema penelitian yang diteliti, diperlukan tahapan-tahapan sebagai berikut: a) Penelitian Kepustakaan. Penelitian kepustakaan

${ }^{12}$ Lihat, Pasal 1 Format Perjanjian Akad Qardhul Hasan pada Bank Muamalat. 
untuk mendapatkan data sekunder, yang terdiri dari: (1) Bahan hukum primer; (2) Bahan hukum sekunder, dan (3) Bahan hukum tertier. b) Penelitian Lapangan, digunakan metode wawancara (interview), dengan menggunakan kuesioner terbuka maupun tertutup melalui wawancara mendalam (dept interview).

Analisis pembahasan melalui kajian yang bersifat normatif, yakni kajian dengan mengambil ketentuan-ketentuan hukum maupun asas-asas hukum dari sistem hukum umum maupun sistem hukum Islam. Adapun pendekatan kajian ini, dipergunakan pendekatan konsep (conceptual approach) dan pendekatan analisis normatif (normative approach analysis). Di samping itu, analisis kuantitatif akan digunakan sebagai pelengkap untuk mendukung atau sebagai pelengkap analisis kualitatif. Data yang diperoleh dianalisis secara induktif dan deduktif untuk mendapatkan suatu gambaran dan kesimpulan sedemikian rupa dengan menggunakan pendekatan normatif yuridis dan yuridis empiris sehingga akan melibatkan aspek hukum Islam, hukum positif, sejarah, ekonomi, dan kebijakan publik.

\section{Hasil Penelitian dan Pembahasan}

\section{Pertanggungjawaban Sosial Perusahaan (Corporate Social Responsibility) Perbankan Syariah}

Program pertanggungjawaban sosial perusahaan (Corporate Social Responsibility, selanjutnya disebut CSR) merupakan investasi jangka panjang yang berguna untuk meminimalisasi risiko sosial, dan berfungsi sebagai sarana meningkatkan citra perusahaan di mata publik. Di Indonesia, penerapan CSR sudah cukup menggembirakan. Banyak perusahaan melakukan amal baik dengan menunjukkan kepeduliannya terhadap masyarakat dan lingkungan sekitarnya. Sudah saatnya perusahaan-perusahaan, termasuk perbankan syariah di Indonesia menjalankan CSR dengan sepenuh hati. ${ }^{13}$

Dalam Undang-Undang No. 40 Tahun 2007 tentang Perseroan Terbatas menegaskan tentang definisi tanggung jawab sosial dan lingkungan adalah

${ }^{13}$ Perdebatan tentang CSR tidak hanya terjadi pada wacana akademik saja, tetapi juga pada implementasinya dalam perusahaan-perusahaan di dunia. Kurun sepuluh tahun terakhir, perdebatan ini memberikan pengaruh yang signifikan dalam dunia perusahaan dan birokrasi di Indonesia. Lihat, Edi Suharto, "CSR: Konsep dan Perkembangan Pemikiran”, makalah pembicara pada Workshop Tanggung Jawab Sosial Perusahaan, Yogyakarta, 6-8 Mei 2008. 
komitmen perseroan untuk berperan serta dalam pembangunan ekonomi berkelanjutan guna meningkatkan kualitas kehidupan dan lingkungan yang bermanfaat, baik bagi perseroan sendiri, komunitas setempat, maupun masyarakat pada umumnya. ${ }^{14}$

CSR adalah sebuah pendekatan dimana perusahaan mengintegrasikan kepedulian sosial dalam operasi bisnis mereka dan dalam interaksi mereka dengan para pemangku kepentingan (stakeholders) berdasarkan prinsip kesukarelaan dan kemitraan. ${ }^{15}$

Secara esensial CSR merupakan wujud dari giving back (mengembalikan) perusahaan (korporasi) kepada masyarakat (komunitas). Dalam hal ini, CSR dapat dilakukan dengan cara melakukan dan menghasilkan bisnis berdasar pada niat tulus guna memberikan kontribusi paling positif pada komunitas (stakeholderss). ${ }^{16}$

Oleh karena itu, pentingnya pengaturan CSR di Indonesia, agar memiliki daya atur, daya ikat dan daya dorong. CSR yang semula bersifat voluntary perlu ditingkatkan menjadi CSR yang lebih bersifat mandatory. Dengan sifat ini, diharapkan kontribusi dunia usaha yang terukur dan sistematis dalam ikut meningkatan kesejahteraan masyarakat. Kebijakan yang pro-masyarakat dan lingkungan seperti ini sangat dibutuhkan ditengah arus neoliberalisme seperti sekarang ini. Sebaliknya di sisi lain, masyarakat juga tidak bisa seenaknya melakukan tuntutan kepada perusahaan, apabila harapannya itu berada diluar batas aturan yang berlaku. ${ }^{17}$

Di Indonesia, regulasi mengenai CSR telah di atur oleh pemerintah sejak 1994 dengan dikeluarkannya Keputusan Menteri Keuangan Republik Indonesia No. 316/ KMK 016/1994 tentang Program Pembinaan Usaha Kecil dan Koperasi oleh Badan Usaha Milik Negara, yang kemudian dikukuhkan lagi dengan Keputusan Menteri Negara Badan Usaha Milik Negara No. Kep-236/MBU/2003 menetapkan bahwa

${ }^{14}$ Pasal 1 angka 3 Undang-Undang No. 40 Tahun 2007, tentang Perseroan Terbatas, yang telah ditetapkan dan diundangkan dengan Lembaran Negara Republik Indonesia Tahun 2007 No. 106, Tambahan Lembaran Negara Republik Indonesia No. 4756. Pasal 74 Undang-undang ini juga menyebutkan : 1) Perseroan yang menjalankan kegiatan usahanya di bidang dan/atau berkaitan dengan sumber daya alam wajib melaksanakan Tanggung Jawab Sosial dan Lingkungan. 2) Tanggung Jawab Sosial dan Lingkungan sebagaimana dimaksud pada ayat (1) merupakan kewajiban Perseroan yang dianggarkan dan diperhitungkan sebagai biaya Perseroan yang pelaksanaannya dilakukan dengan memperhatikan kepatutan dan kewajaran;

${ }^{15}$ Mu'man Nuryana, “Corporate Social responsibility dan Kontribusi bagi Pembangunan Berkelanjutan”, makalah yang disampaikan pada Diklat Pekerjaan Sosial Industri, Balai Besar Pendidikan dan Pelatihan Kesejahteraan Sosial (BBPPKS) Bandung, Lembang 5 Desember 2005, hlm. 4.

${ }^{16}$ Reza Rahman, Corporate Social Responsibility: Antara Teori dan Kenyataan, Buku Kita, Jakarta, 2009, hlm. 10.

${ }^{17}$ Bing Bedjo Tanudjaya, "Perkembangan Corporate Social Rensponsibility di Indonesia", Jurnal Nirmana, Jakarta, Vol.8, No. 2, Juli, 2006, hlm. 93. 
setiap perusahaan diwajibkan menyisihkan laba setelah pajak sebesar $1 \%$ (satu persen) sampai dengan 3\% (tiga persen). untuk menjalankan CSR. ${ }^{18}$

Sekarang ini, kewajiban melaksanakan CSR bukan hanya dibebankan pada Badan Usaha Milik Negara (BUMN). Pengaturan CSR secara tegas diatur dalam perundang-undangan. Melalui Undang-Undang No. 40 Tahun 2007 tentang Perseroan Terbatas (UU PT) ${ }^{19}$ dan Undang-Undang No. 25 Tahun 2007 tentang Penanaman Modal (UU PM) ${ }^{20}$, maka setiap perseroan atau penanam modal diwajibkan untuk melakukan sebuah upaya pelaksanaan tanggung jawab perusahaan yang telah dianggarkan dan diperhitungkan sebagai biaya Perseroan. Kebijakan ini juga mengatur sanksi bagi perusahaan yang tidak menjalankan kewajiban tersebut.

Dalam Undang-Undang No. 25 Tahun 2007, tentang Penanaman Modal ditegaskan bahwa "setiap penanam modal berkewajiban melaksanakan tanggung jawab sosial perusahaan" ${ }^{21}$, penjelasan ini menyebutkan yang dimaksud dengan "tanggung jawab sosial perusahaan" adalah tanggung jawab yang melekat pada setiap perusahaan penanaman modal untuk tetap menciptakan hubungan yang serasi, seimbang dan sesuai dengan lingkungan, nilai, norma dan budaya masyarakat setempat. $^{22}$

Sedangkan dalam Undang-Undang No. 40 Tahun 2007, tentang Perseroan Terbatas menegaskan tentang definisi tanggung jawab sosial dan lingkungan adalah komitmen perseroan untuk berperan serta dalam pembangunan ekonomi berkelanjutan guna meningkatkan kualitas kehidupan dan lingkungan yang bermanfaat, baik bagi perseroan sendiri, komunitas setempat, maupun masyarakat pada umumnya. ${ }^{23}$

${ }^{18}$ Lihat, Pasal 8 ayat (1) dan (2) Keputusan Menteri Negara Badan Usaha Milik Negara Nomor: Kep-236/ MBU/2003 tentang Program Kemitraan BUMN dengan Usaha Kecil dan Program Bina Lingkungan.

${ }^{19}$ Pasal 74 (1) Perseroan yang menjalankan kegiatan usahanya di bidang dan/atau berkaitan dengan sumber daya alam wajib melaksanakan Tanggung Jawab Sosial dan Lingkungan; (2) Tanggung Jawab Sosial dan Lingkungan sebagaimana dimaksud pada ayat (1) merupakan kewajiban Perseroan yang dianggarkan dan diperhitungkan sebagai biaya Perseroan yang pelaksanaannya dilakukan dengan memperhatikan kepatutan dan kewajaran; (3) Perseroan yang tidak melaksanakan kewajiban sebagaimana dimaksud pada ayat (1) dikenai sanksi sesuai dengan ketentuan peraturan perundang-undangan; (4) Ketentuan lebih lanjut mengenai Tanggung Jawab Sosial dan Lingkungan diatur dengan peraturan pemerintah.

${ }^{20}$ Pasal 15(b) Setiap penanam modal berkewajiban melaksanakan tanggung jawab sosial perusahaan; Pasal 16 (d) Setiap penanam modal bertanggung jawab menjaga kelestarian lingkungan hidup;

${ }^{21}$ Pasal 15 huruf b Undang-Undang No. 25 Tahun 2007 tentang Penanaman Modal.

22 Penjelasan Pasal 15 huruf b Undang-Undang No. 25 Tahun 2007 tentang Penanaman Modal.

${ }^{23}$ Pasal 1 angka 3 Undang-Undang No. 40 Tahun 2007 tentang Perseroan Terbatas, yang telah ditetapkan dan diundangkan dengan Lembaran Negara Republik Indonesia Tahun 2007 No. 106, Tambahan Lembaran Negara Republik Indonesia No. 4756. 
Dalam Undang-Undang No. 25 Tahun 2007 tentang Penanaman Modal, menyatakan bahwa tanggungjawab sosial perusahaan adalah tanggungjawab yang melekat pada setiap perusahaan penanaman modal untuk menciptakan hubungan yang serasi, seimbang dan sesuai dengan lingkungan, nilai, norma dan budaya masyarakat setempat. ${ }^{24}$

Hal ini, senada dengan Undang-Undang No. 40 Tahun 2007 tentang Perseroan Terbatas, yang menegaskan bahwa tanggungjawab sosial dan lingkungan adalah komitmen Perseroan untuk berperan serta dalam pembangunan ekonomi berkelanjutan guna meningkatkan kualitas kehidupan dan lingkungan yang bermanfaat, baik bagi Perseroan sendiri, komunitas setempat,maupun masyarakat pada umumnya.

Dalam Peraturan Pemerintah No. 47 Tahun 2012 tentang Tanggung Jawab Sosial dan Lingkungan Perseroan Terbatas, menjadi kewajiban bagi Perseroan yang menjalankan kegiatan usahanya di bidang dan/atau berkaitan dengan sumber daya alam berdasarkan Undang-Undang. Kewajiban ini dilaksanakan baik di dalam maupun di luar lingkungan Perseroan.

Menurut Penjelasan Pasal 3 ayat (1) Peraturan Pemerintah tersebut, yang dimaksud dengan "Perseroan yang menjalankan kegiatan usahanya di bidang sumber daya alam" adalah perseroan yang kegiatan usahanya mengelola dan memanfaatkan sumber daya alam. Adapun "Perseroan yang menjalankan kegiatan usahanya yang berkaitan dengan sumber daya alam" adalah Perseroan yang tidak mengelola dan tidak memanfaatkan sumber daya alam, tetapi kegiatan usahanya berdampak pada fungsi kemampuan sumber daya alam termasuk pelestarian fungsi lingkungan hidup. Sedangkan, yang dimaksud dengan "berdasarkan UndangUndang" adalah undang-undang beserta peraturan pelaksanaan undang-undang mengenai sumber daya alam atau yang berkaitan dengan sumber daya alam, serta etika menjalankan perusahaan, antara lain: peraturan perundang-undangan di bidang perindustrian, kehutanan, minyak dan gas bumi, badan usaha milik negara, usaha panas bumi, sumber daya air, pertambangan mineral dan batu bara, ketenagalistrikan, perlindungan dan pengelolaan lingkungan hidup, larangan praktik monopoli dan persaingan usaha tidak sehat, hak asasi manusia, ketenagakerjaan, serta perlindungan konsumen.

Penjelasan di atas dapat dilihat bahwa CSR bukan lagi sesuatu yang asing bagi perusahaan. Pelaksanaan CSR merupakan suatu wujud apresiasi dalam penciptaan

${ }^{24}$ Penjelasan Pasal 15 huruf (b) Undang-Undang Nomor 25 Tahun 2007 tentang Penanaman Modal. 
kehidupan yang lebih baik dan berkelanjutan. Oleh karena itu, bagian yang tidak kalah penting dalam pelaksanaan CSR adalah kesepahaman pandangan tentang konsep dan bentuk yang akan dijalankan.

Dalam perspektif pengertian CSR yang dituangkan dalam Undang-Undang No. 25 Tahun 2007 tentang Penanaman Modal dan Undang-Undang No. 40 Tahun 2007 tentang Perseroan Terbatas terjadi perbedaan penafsiran yang akan menimbulkan persoalan di kemudian hari.

Menurut Mukti Fajar ND, perbedaan terminologi antara CSR yang tertuang dalam Undang-Undang No. 25 Tahun 2007 tentang Penanaman Modal dan UndangUndang No. 40 Tahun 2007 tentang Perseroan Terbatas menjadi hambatan bagi setiap perusahaan untuk menterjemahkan dalam teknis pelaksanaan CSR. Hal ini karena: (1) istilah yang digunakan dalam Undang-Undang No. 25 Tahun 2007 tentang Penanaman Modal adalah tanggung jawab sosial perusahaan dan tanggung jawab yang melekat; (2) sedangkan dalam Undang-Undang No. 40 Tahun 2007 tentang Perseroan Terbatas; kata "komitmen perseroan" dan "tanggung jawab yang melekat" tidak dapat diartikan sama dengan tanggung jawab sosial; (3) Undang-Undang No. 40 Tahun 2007 tentang Perseroan Terbatas berorientasi pada peningkatan kualitas hidup masyarakat, sedangkan Undang-Undang No. 25 Tahun 2007 tentang Penanaman Modal lebih berorientasi menciptakan hubungan yang serasi. ${ }^{25}$

Di samping itu, dalam pelaksanaan CSR, Undang-Undang No. 25 Tahun 2007 tentang Penanaman Modal tidak ada batasan terhadap bentuk perusahaan dan bidang usahanya, sedangkan dalam Undang-Undang No. 40 tahun 2007 tentang Perseroan Terbatas, CSR hanya diperuntukan bagi bentuk perusahaan Perseroan Terbatas khusus yang bergerak di bidang sumber daya alam dan yang terkait, seperti disebutkan dalam Pasal 74 ayat (1), yaitu: "Perseroan yang menjalankan kegiatan usahanya di bidang dan/atau berkaitan dengan sumber daya alam wajib melaksanakan tanggung jawab sosial dan lingkungan."26

Perspektif di atas, ada dua hal yang perlu diperhatikan, yaitu: pertama, hanya Perseroan yang menjalankan kegiatan usahanya di bidang dan/atau berkaitan dengan sumber daya alam wajib melaksanakan tanggung jawab sosial dan lingkungan. Hal ini dipertegas lagi dengan Peraturan Pemerintah Nomor 47 Tahun

\footnotetext{
${ }^{25}$ Mukti Fajar ND., Tanggung Jawab Sosial Perusahaan di Indonesia: Studi tentang Penerapan CSR pada Perusabaan Multinasional, Swasta Nasional dan BUMN di Indonesia, cet.I, Pustaka Pelajar, Yogyakarta, 2010, hlm. 3.

${ }^{26}$ Ibid.
} 
2012 tentang Tanggung Jawab Sosial dan Lingkungan Perseroan Terbatas, yang menyebutkan "Perseroan Terbatas yang selanjutnya disebut Perseroan adalah badan hukum yang merupakan persekutuan modal, didirikan berdasarkan perjanjian, melakukan kegiatan usaha dengan modal dasar yang seluruhnya terbagi dalam saham dan memenuhi persyaratan yang ditetapkan dalam Undang-Undang No. 40 Tahun 2007 tentang Perseroan Terbatas serta peraturan pelaksanaannya". ${ }^{27}$ Setiap Perseroan selaku subjek hukum mempunyai tanggung jawab sosial dan lingkungan. ${ }^{28}$ Tanggung jawab sosial dan lingkungan tersebut menjadi kewajiban bagi Perseroan yang menjalankan kegiatan usahanya di bidang dan/atau berkaitan dengan sumber daya alam berdasarkan Undang-Undang. ${ }^{29}$ Yang dimaksud dengan "Perseroan yang menjalankan kegiatan usahanya di bidang sumber daya alam" adalah Perseroan yang kegiatan usahanya mengelola dan memanfaatkan sumber daya alam. ${ }^{30}$ Sedangkan, yang dimaksud dengan "Perseroan yang menjalankan kegiatan usahanya yang berkaitan dengan sumber daya alam" adalah Perseroan yang tidak mengelola dan tidak memanfaatkan sumber daya alam, tetapi kegiatan usahanya berdampak pada fungsi kemampuan sumber daya alam termasuk pelestarian fungsi lingkungan hidup. Yang dimaksud dengan "berdasarkan UndangUndang" adalah undang-undang beserta peraturan pelaksanaan undang-undang mengenai sumber daya alam atau yang berkaitan dengan sumber daya alam, serta etika menjalankan perusahaan, antara lain: peraturan perundang-undangan di bidang perindustrian, kehutanan, minyak dan gas bumi, badan usaha milik negara, usaha panas bumi, sumber daya air, pertambangan mineral dan batu bara, ketenagalistrikan, perlindungan dan pengelolaan lingkungan hidup, larangan praktik monopoli dan persaingan usaha tidak sehat, hak asasi manusia, ketenagakerjaan, serta perlindungan konsumen. ${ }^{31}$ Dengan demikian, aspek tanggung jawab sosial dan lingkungan menjadi keharusan semua perusahaan patuh terhadap segala jenis peraturan dan berlaku untuk semua perseroan, bukan sekadar

\footnotetext{
${ }^{27}$ Pasal 1 angka 1 Peraturan Pemerintah No. 47 Tahun 2012 tentang Tanggung Jawab Sosial dan Lingkungan Perseroan Terbatas.

${ }^{28}$ Pasal 2 Peraturan Pemerintah No. 47 Tahun 2012 tentang Tanggung Jawab Sosial dan Lingkungan Perseroan Terbatas.

${ }^{29}$ Pasal 3 ayat (1) Peraturan Pemerintah No. 47 Tahun 2012 tentang Tanggung Jawab Sosial dan Lingkungan Perseroan Terbatas.

${ }^{30}$ Penjelasan Pasal 3 ayat (1) Peraturan Pemerintah Nomor: 47 Tahun 2012 tentang Tanggung Jawab Sosial dan Lingkungan Perseroan Terbatas

${ }^{31}$ Penjelasan Pasal 3 ayat (1) Peraturan Pemerintah Nomor 47 Tahun 2012 tentang Tanggung Jawab Sosial dan Lingkungan Perseroan Terbatas
} 
untuk perusahaan ekstraktif. Tanggung Jawab Sosial dan Lingkungan berdasarkan Peraturan Pemerintah No. 47 Tahun 2012 tersebut, menekankan pada: 1) kepatuhan atas peraturan (legal compliance); 2) dimensi sosial dan lingkungan;3) hubungan yang serasi perseroan dan masyarakat; dan 4) bentuk manajemen risiko.

Kedua, apakah Perseroan Terbatas yang tidak bergerak di bidang dan/atau berkaitan dengan sumber daya alam dianggap tidak dibebani kewajiban CSR? Persoalan ini akan berdampak pada Perseroan Terbatas yang berbentuk Bank, misalnya: PT Bank Muamalat Indonesia Tbk, yang tunduk pada hukum perseroan di Indonesia, sebagaimana Undang-Undang Nomor 40 Tahun 2007 tentang Perseroan Terbatas. PT Bank Muamalat Indonesia Tbk, adalah perseroan yang menjalankan program kebijakan negara dalam bidang perekonomian dan kesejahteraan sosial melalui usaha perbankan syariah. Usaha perbankan syariah bukan bidang dan/ atau berkaitan dengan sumber daya alam, apakah tidak dibebani kewajiban CSR? Pertanyaan ini muncul jika dikaitkan dengan rumusan CSR yang hanya diperuntukan bagi bentuk perusahaan Perseroan Terbatas khusus yang bergerak di bidang sumber daya alam dan yang terkait, seperti disebutkan dalam Pasal 74 ayat (1) UndangUndang Nomor 40 Tahun 2007 tentang Perseroan Terbatas di atas.

Berkaitan dengan CSR, maka yang dimaksud dengan perusahaan adalah badan usaha yang berbadan hukum yang tunduk pada hukum perseroan dan hukum penanaman modal sebagaimana pengaturan dalam Undang-Undang No. 40 Tahun 2007 tentang Perseroan Terbatas dan Undang-Undang No. 25 Tahun 2007 tentang Penanaman Modal.

Sedikitnya ada empat model atau pola CSR yang umumnya diterapkan oleh perusahaan di Indonesia, yaitu: ${ }^{32}$ a) Keterlibatan langsung. Perusahaan menjalankan program CSR secara langsung dengan menyelenggarakan sendiri kegiatan sosial atau menyerahkan sumbangan ke masyarakat tanpa perantara. Untuk menjalankan tugas ini, sebuah perusahaan biasanya menugaskan salah satu pejabat seniornya, seperti corporate secretary atau public affair manager atau menjadi bagian dari tugas pejabat public relation; b) Melalui yayasan atau organisasi sosial perusahaan. Perusahaan mendirikan yayasan sendiri di bawah perusahaan atau groupnya. Model ini merupakan adopsi dari model yang lazim diterapkan di perusahaan-perusahaan di negara maju. Biasanya, perusahaan menyediakan dana awal, dana rutin atau dana abadi yang dapat digunakan secara teratur bagi kegiatan yayasan; c) Bermitra dengan

${ }^{32}$ Zaim Saidi, Op.Cit., hlm. 64-65. 
pihak lain. Perusahaan menyelenggarakan CSR melalui kerjasama dengan lembaga sosial/organisasi non-pemerintah (NGO/ LSM), instansi pemerintah, universitas atau media massa, baik dalam mengelola dana maupun dalam melaksanakan kegiatan sosialnya; dan d) Mendukung atau bergabung dalam suatu konsorsium. Perusahaan turut mendirikan, menjadi anggota atau mendukung suatu lembaga sosial yang didirikan untuk tujuan sosial tertentu. Dibandingkan dengan model lainnya, pola ini lebih berorientasi pada pemberian hibah perusahaan yang bersifat "hibah pembangunan". Pihak konsorsium atau lembaga semacam itu yang dipercayai oleh perusahaan-perusahaan yang mendukungnya secara pro aktif mencari mitra kerjasama dari kalangan lembaga operasional dan kemudian mengembangkan program yang disepakati bersama.

\section{Pelaksanaan Al-Qardh dan Al-Qardhul Hasan dan Corporate Social Responsibility (Csr) pada PT. Bank Muamalat Indonesia Tbk}

Pelaksanaan program al-qardh dan al-qardhul hasan didasarkan pada fatwa DSNMUI Nomor: 19/DSN-MUI/IV/ 2001 tentang al-Qardh, Peraturan Bank Indonesia (PBI) No. 7/46/PBI/2005 tentang Akad Penghimpunan dan Penyaluran Dana bagi Bank yang Melaksanakan Kegiatan Usaha Berdasarkan Prinsip Syariah; dan Peraturan Bank Indonesia (PBI) No. 9/19/PBI/ 2007 tentang Pelaksanaan Prinsip Syariah dalam Kegiatan Penghimpunan Dana dan Penyaluran Dana serta Pelayanan Jasa Bank Syariah.

Berdasarkan aturan tersebut, BMI menetapkan ketentuan tentang pelaksanaan qardhul hasan adalah sebagai berikut: ${ }^{33} 1$ ) Pinjaman Qardh adalah penyediaan dana atau tagihan yang dapat dipersamakan dengan itu berdasarkan persetujuan atau kesepakatan antara peminjam dan Bank yang mewajibkan peminjam melunasi hutangnya setelah jangka waktu tertentu; 2) Bank dapat menerima imbalan namun tidak boleh mensyaratkan adanya imbalan tersebut dalam perjanjian. Imbalan jika diberikan diakui sebagai pendapatan pada saat diterima; 3) Pinjaman Qardh diakui sebesar jumlah dana yang dipinjamkan pada saat terjadinya. Kelebihan penerimaan dari pinjaman atas Qardh yang dilunasi diakui sebagai pendapatan pada saat terjadinya; dan 4) Pinjaman Qardh disajikan sebesar saldo pinjaman dikurangi penyisihan kerugian.

${ }^{33}$ Bank Muamalat Indonesia, Buku Pedoman Produk Qardhul Hasan Tahun 2010 
Pelaksanaan al-qardh dan al-qardhul hasan dalam BMI, adalah, a) Pelaku yang terdiri dari pemberi dan penerima pinjam; b) Obyek akad, berupa uang yang dipinjamkan; dan c) Ijab Kabul (serah terima). Adapun ketentuannya adalah pelaku harus cakap hukum dan baligh. Obyek akad, ketentuannya adalah: 1) jelas nilai pinjamannya dan waktu pelunasannya; 2) Peminjam diwajibkan membayar pokok pinjaman pada waktu yang telah disepakati, tidak boleh diperjanjikan akan ada penambahan atas pokok pinjamannya. Namun peminjam dibolehkan memberikan sumbangan secara sukarela; 3)Apabila memang peminjam mengalami kesulitan keuangan, maka waktu peminjaman dapat diperpanjang atau menghapuskan sebagian atau seleruh kewajibannya. Namun, jika peminjam lalai maka dapat dikenakan denda. Sedangkan, Ijab Kabul adalah pernyataan dan ekspresi saling rida/rela di antara para pihak pelaku akad yang dilakukan secara verbal dan tertulis melalui korespondensi atau menggunakan cara-cara komunikasi modern. ${ }^{34}$

Apabila dalam pelaksanaan akad al-qardh dan al-qardhul hasan, salah satu pihak tidak menunaikan kewajibannya atau jika terjadi perselisihan di antara para pihak, maka penyelesaiannya dilakukan melalui Badan Arbitrasi Syari'ah Nasional

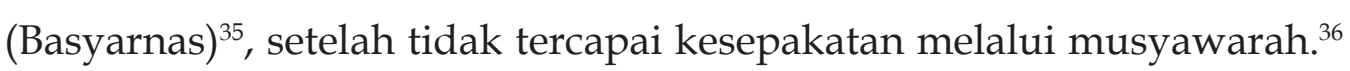

Adapun ketentuan sumber dana al-qardh dan al-qardhul hasan, BMI mencari sumber dana dari, 1) Bagian modal Bank; 2) Keuntungan Bank yang disisihkan; dan 3) Lembaga lain atau individu yang mempercayakan penyaluran infaqnya kepada perbankan syariah. ${ }^{37}$

Produk pinjaman al-qardh dan al-qardhul hasan yang diterapkan oleh BMI, diperuntukkan pada hal-hal berikut: a) Sebagai pinjaman talangan haji, di mana nasabah calon haji diberikan pinjaman talangan untuk memenuhi syarat penyetoran biaya haji. Nasabah akan melunasinya sebelum keberangkatannya ke tanah suci; b) Sebagai pinjaman tunai (cash advanced) dari produk kartu kredit syariah, dimana nasabah diberi keleluasaan untuk menarik uang tunai milik bank melalui ATM.

\footnotetext{
${ }^{34}$ Ibid.

${ }^{35}$ Badan Arbitrase Syariah Nasional (Basyarnas) merupakan salah satu wujud dari Arbitrase Islam yang pertama kali didirikan di Indonesia. Kehadirannya karena dilatar belakangi oleh kesadaran dan kepentingan umat untuk melaksanakan syariat Islam, melainkan juga lebih dari itu adalah menjadi kebutuhan riil sejalan dengan perkembangan kehidupan ekonomi dan keuangan di kalangan umat. Karena itu, tujuan dan fungsi adalah menyelesaikan kemungkinan terjadinya sengketa muamalat yang timbul dalam hubungan perdagangan, industri keuangan, jasa dan lain-lain dikalangan umat Islam. Lihat, http:/ $/$ www. mui.or.id/index.php? option=com content\&view $=$ article\&id $=57 \& I t e m i d=83$, diakses pada tanggal 12 Pebruari 2012.

${ }^{36}$ Bank Muamalat Indonesia, Buku Pedoman Produk Qardhul Hasan Tahun 2010.

${ }^{37}$ Ibid.
} 
Nasabah akan mengembalikannya sesuai waktu yang telah ditentukan; c) Sebagai pinjaman kepada pengusaha kecil, dimana menurut perhitungan bank akan memberatkan si pengusaha bila diberikan pembiayaan dengan skema jual beli, ijarah, atau bagi hasil; d) Sebagai pinjaman kepada pengurus bank, dimana bank menyediakan fasilitas ini untuk memastikan terpenuhinya kebutuhan pengurus bank. Pengurus bank akan mengembalikannya secara cicilan melalui pemotongan gajinya; e) Sebagai produk pelengkap kepada nasabah yang telah terbukti loyalitas dan bonafiditasnya, yang membutuhkan dana talangan segera untuk masa yang relatif pendek. Nasabah tersebut akan mengembalikan secepatnya sejumlah uang yang dipinjamnya; f) Sebagai fasilitas nasabah yang memerlukan dana cepat, sedangkan ia tidak bisa menarik dananya karena misalnya tersimpan dalam bentuk deposito; dan g) Sebagai produk untuk menyumbang usaha yang sangat kecil atau membantu sektor sosial.

Pada akhir 2010 al-qardh dan al-qardhul hasan, yang berhasil didistribusikan sebesar Rp.1.195.650.000.000,00, meningkat 290,21\% jika dibandingkan 2009, yang tercatat sebesar Rp. 306.410.000.000,00. Peningkatan yang sangat signifikan ini dipicu oleh peningkatan pembiayaan dana talangan haji yang tumbuh seiring minat masyarakat yang juga tinggi dalam melakukan ibadah haji. Peningkatan pembiayaan dana talangan haji pun didukung oleh strategi Bank Muamalat dalam mendapatkan nasabah dengan berkerjasama dengan kelompok bimbingan ibadah haji maupun penyelenggara haji.

Dalam Pelaksanaan CSR pada PT BMI didasarkan atas Pasal 15 ayat (b) Undang-Undang No. 25 Tahun 2007 tentang Penanaman Modal yang mengamanahkan yang menegaskan agar "Setiap penanaman modal berkewajiban melaksanakan tanggung jawab sosial perusahaan". ${ }^{38}$ Disamping itu, untuk memenuhi ketentuan Good Corporate Governance (GCG) terkait kewajiban penyaluran dana sosial perusahaan diperlukan suatu program CSR.

Untuk pelaksanaan CSR PT Bank Muamalat Indonesia telah mengalokasikan dana sebesar 2,5\% dari laba perusahaan yang penyaluran dananya dilakukan melalui Baitulmaal Muamalat (BMM). ${ }^{39}$ BMM mempunyai visi yang jelas, yaitu menjadi motor penggerak program kemandirian ekonomi ummat menuju terwujudnya tatanan masyarakat yang berkarakter, tumbuh dan peduli (empowering a caring society). Adapun

\footnotetext{
${ }^{38}$ Iwan Agustiawan, Sekretaris BMM, Wawancara tanggal 12 Januari 2012

${ }^{39}$ Baitulmaal Muamalat (BMM) merupakan yayasan yang didirikan oleh Bank Muamalat pada 16 Juni 2000 sebagai perpanjangan tangan perseroan dalam melaksanakan kegiatan CSR dan kegiatan sosial lainnya. Pelaksanaan kegiatan sosial yang dilakukan BMM bersumber dari alokasi dana CSR Bank Muamalat, dana ZIS (Zakat, Infak, Sedekah) perseroan, karyawan dan nasabah Bank Muamalat, serta dana Non-ZIS perusahaan dan dana sosial lainnya.
} 
misi yang dituju oleh BMM adalah, a) Melaksanakan program pemberdayaan ekonomi dan sosial masyarakat secara terintegral dan komprehensif; dan b) Membangun dan mengembangkan jaringan kerja pemberdayaan seluasnya. ${ }^{40}$

Pelaksanaan kegiatan sosial yang dilakukan BMM bersumber dari dana ZIS (Zakat, Infaq dan Sadaqah) Bank Muamalat, karyawan dan nasabah, dana CSR, dan dana sosial lainnya, serta dana non-halal yang diterima Bank Muamalat seperti pendapatan yang bersumber dari penempatan dana pada bank konvensional. ${ }^{41}$

Selama tahun 2010 telah disalurkan dana CSR sebesar Rp. 22.800.000.000,00 dari total dana penerimaan untuk kegiatan sosial, sebesar Rp. 27.700.000.000,00. ${ }^{42}$ Adapun selama 2011, Bank Muamalat telah menyalurkan dana CSR sebesar Rp. 11.600.000.000,00 dari total penerimaan sebesar Rp. 32.500.000.000,00. ${ }^{43}$

Dalam aktivitas BMI dalam menjalankan fungsi sosialnya melalui pembiayaan al-qardh dan al-qardhul hasan, telah dijalankan dengan perbandingan rasio pembiayaan al-qardh dan al-qardhul hasan atau qardh ratio (QR) dengan total pembiayaan yang disalurkan BMI. QR digunakan untuk mengukur besarnya kontribusi pembiayan al-qardh perbankan syariah tersebut. QR dihitung dengan membandingkan pembiayaan qardh dengan total pembiayaan yang dilakukan oleh perbankan syariah. Semakin tinggi komponen pembiayaan ini, mengindikasikan kepedulian bank syariah yang tinggi kepada pihak yang mengalami kesulitan.

Penerimaan dana tersebut mengalami peningkatan sebesar 18\% dibandingkan dengan 2010 yang hanya sebesar Rp. 27.700.000.000,00. Pertumbuhan tersebut, merupakan wujud dari meningkatnya kepercayaan masyarakat dan lembaga lainnya untuk menyalurkan dana sosial mereka kepada BMM. Tidak hanya kepada BMM itu sendiri, secara tidak langsung pencapaian tersebut juga merupakan bentuk dari kontribusi Bank Muamalat sebagai pendiri BMM untuk mensejahterakan ekonomi masyarakat dengan prinsip syariah, peningkatan kualitas hidup dan kepedulian terhadap lingkungan yang dijalankan melalui program-program BMM.

Berdasarkan hasil penelitian terhadap pelaksanaan produk al-qardh dan al-qardhul hasan di PT. Bank Muamalat Indonesia (BMI), bahwa produk al-qardh dan al-qardhul hasan merupakan salah satu "ciri pembeda" bank syariah dengan bank konvensional. Dalam produk ini terkandung misi sosial kemasyarakatan sebagai wujud

\footnotetext{
${ }^{40}$ Iwan Agustiawan, Wawancara, tanggal 12 Januari 2012

${ }^{41}$ Iwan Agustiawan, Wawancara, tanggal 12 Januari 2012

${ }^{42}$ Laporan Tahunan PT Bank Muamalat Indonesia tahun 2010, Jakarta, Juli 2011, hlm 214.

${ }^{43}$ Laporan Tahunan PT Bank Muamalat Indonesia tahun 2011, Jakarta, Juli 2011, hlm. 258.
} 
tanggung jawab sosial PT. BMI kepada masyarakat. Misi sosial kemasyarakatan ini bertujuan untuk meningkatkan pemberdayaan masyarakat, meningkatkan citra bank dan meningkatkan loyalitas masyarakat terhadap bank syariah.

Di samping itu, produk qardhul hasan sebagai produk sosial telah memberikan manfaat bagi masyarakat yang membutuhkan pembiayaan tersebut. Hasil penelitian membuktikan bahwa manfaat pembiayaan qardhul hasan sangat dirasakan oleh kalangan kelas menengah ke bawah.

\section{Penutup}

Pertama, tanggung jawab sosial perusahaan (corporate social responsibility) perbankan syariah dimaknai sebagai instrumen untuk meningkatkan kinerja dan pelayanan pada masyarakat. Ada dua versi penerapan program CSR, yaitu: a) program CSR tersebar pada berbagai aktivitas utama seperti, bantuan uang (dana) untuk pendidikan (beasiswa dan pembelian peralatan pendidikan), kesehatan, kemiskinan, sosial, agama, infrastruktur, dan lingkungan hidup. Hal ini, karena sumber dana utama CSR perbankan syariah diambil dari keuntungan bank dalam menjalankan produkproduk komersialnya. Inilah yang kemudian dipersepsikan menjadi bantuan keuangan kepada masyarakat yang tidak perlu dikembalikan; b) program CSR dilakukan melalui salah satu produk pembiayaan, yaitu produk pembiayaan alqardh dan al-qardhul hasan sebagai wujud misi sosial perbankan syariah. Sumber dana utama produk ini adalah dari zakat, infak, sadaqah, dan sumber-sumber dana lainnya yang diperoleh perbankan syariah. Penerapan produk ini terus bergulir yang mewajibkan penerima dana mengembalikan pinjaman uangnya kepada bank, yang dapat diberikan lagi kepada peminjam lainnya. Program al-qardhul hasan inilah yang, akhirnya, berorientasi pada pemberdayaan masyarakat ekonomi lemah. Kedua, program al-qardh dan al-qardhul hasan adalah produk yang berlandaskan pada hukum al-qardh. Produk ini menjadi "ciri khas" perbankan syariah, khususnya pada PT Bank Muamalat Tbk. Dalam pelaksanaannya belum ada regulasi spesifik (khusus) yang mengatur pelaksanaan al-qardh dan al-qardhul hasan sebagai CSR pada perbankan syariah, hal ini, karena: a) PT Bank Muamalat Tbk belum merumuskan aplikasi dan implementasi prinsip al-qardh dan al-qardhul hasan dalam upaya mewujudkan kesejahteraan sosial; b) al-qardh dan al-qardhul hasan sebagai misi sosial perbankan syariah, belum ada kesatuan pendapat mengenai apakah program al- 
qardh dan al-qardhul hasan semata-mata sebagai CSR yang "menghilangkan" dana bank atau CSR sebagai “pinjaman” yang wajib dilakukan sebagai bentuk program sosial bank yang berkelanjutan; c) persepsi masyarakat masih menganggap pinjaman al-qardhul hasan sebagai hibah atau bantuan sosial yang tidak perlu mengembalikan pinjaman tersebut. Pemikiran ini seringkali disampaikan juga oleh pemerintah secara tidak langsung lewat program pemerintah yang memberikan bantuan langsung kepada masyarakat; d) produk al-qardh dan al-qardhul hasan merupakan produk pelengkap bank syariah, sehingga menyebabkan pengelolaan al-qardhul hasan belum maksimal.

Kedua, program al-qardh dan al-qardhul hasan merupakan "sumbangsih" perbankan syariah dalam pembangunan perekonomian nasional, melalui penyaluran dana bagi masyarakat golongan kecil dan menengah yang mempunyai prospek kepada: 1) kesejahteraan ekonomi yang diperluas dengan kesempatan kerja dan laju pertumbuhan ekonomi yang optimal; 2) keadilan sosio ekonomi dan distribusi kekayaan dan pendapatan yang merata;3) mobilisasi tabungan untuk pembangunan ekonomi; dan 4) pelayanan yang efektif dan transparan dari sistem perbankan Islam. Prospek program al-qardhul hasan dalam upaya mewujudkan kesejahteraan sosial, adalah sebuah jawaban yang tepat untuk mengatasi dan sebagai sebuah solusi alternatif dari masalah utang piutang yang menimpa hampir seluruh masyarakat Indonesia. Program ini dapat menjadi suatu kewajiban umat muslim kepada muslim lainnya yang akan diberikan kepada orang lain yang membutuhkan dengan prinsip tolong menolong.

\section{Daftar Pustaka}

Abdul Jalil, Ma'ruf, Al-Wajiz, Pustaka As-Sunah, Jakarta, 2006.

Abdullah, Ma'ruf, Hukum Perbankan dan Perkembangan Bank Syariah di Indonesia, Antasari Pers, Banjarmasin, 2006.

Bedjo Tanudjaya, Bing, "Perkembangan Corporate Social Rensponsibility di Indonesia", Jurnal Nirmana, Jakarta Vol. 8, No. 2, Juli, 2006.

Fajar ND., Mukti, Tanggung Jawab Sosial Perusahaan di Indonesia: Studi tentang Penerapan CSR pada Perusahaan Multinasional, Swasta Nasional dan BUMN di Indonesia, cet.I, Pustaka Pelajar, Yogyakarta, 2010.

Mulyadi, Ahmad, Fiqih, Penerbit Titian Ilmu, Bandung, 2006.

Muttaqien, Dadan, "Politik Hukum Pemerintah RI terhadap Perbakan Syariah Pasca disahkannya UU No. 21 Tahun 2008 tentang Perbankan Syariah", makalah Seminar Nasional "Sosialisasi UU No. 21 Tahun 2008 tentang Perbankan Syariah”, Yogyakarta: FIAI UII, 7 Pebruari 2009. 
Nuryana, Mu'man, “Corporate Social responsibility dan Kontribusi bagi Pembangunan Berkelanjutan", makalah yang disampaikan pada Diklat Pekerjaan Sosial Industri, Balai Besar Pendidikan dan Pelatihan Kesejahteraan Sosial (BBPPKS) Bandung, Lembang 5 Desember 2005.

Rahman, Reza, Corporate Social Responsibility: Antara Teori dan Kenyataan, Buku Kita, Jakarta, 2009.

Remy Syahdeini, Sutan, "Perbankan Islam dan Kedudukannya dalam Tata Hukum Perbankan Indonesia", PT Kreatama, Jakarta, 2005.

Sabran, Osman, Urus Niaga al-Qardh al Hasan dalam Pinjaman Tanpa Riba, University Teknologi Malaysia, Kuala Lumpur, 2001.

Suharto, Edi, "CSR: Konsep dan Perkembangan Pemikiran”, makalah pembicara pada Workshop Tanggung Jawab Sosial Perusahaan, Yogyakarta, 6-8 Mei 2008.

Suhendi, Hedi, Fikih Muamalat, RajaGrafindo Persada, Jakarta, 2002.

Format Perjanjian Akad Qardhul Hasan pada Bank Muamalat.

Keputusan Menteri Negara Badan Usaha Milik Negara Nomor: Kep-236/MBU/ 2003 tentang Program Kemitraan BUMN dengan Usaha Kecil dan Program Bina Lingkungan.

Undang-Undang Nomor 21 Tahun 2008 tentang Perbankan Syariah.

Undang-Undang No. 40 Tahun 2007 tentang Perseroan Terbatas.

Peraturan Pemerintah No. 47 Tahun 2012 tentang Tanggung Jawab Sosial dan Lingkungan Perseroan Terbatas

Bank Muamalat Indonesia, Buku Pedoman Produk Qardhul Hasan Tahun 2010.

Laporan Tahunan PT Bank Muamalat Indonesia Tahun 2010.

Laporan Tahunan PT Bank Muamalat Indonesia Tahun 2011.

Undang-Undang Nomor 21 tahun 2008 tentang Perbankan Syariah.

Undang-Undang No. 25 Tahun 2007 tentang Penanaman Modal.

Undang-Undang No. 40 Tahun 2007 tentang Perseroan Terbatas.

Bank Indonesia, Laporan BI: Statistik Perbankan Syariah November 2010, Bank Indonesia, Jakarta.

Bank Indonesia: BI Statistik Perbankan Syariah November 2010.

Bank Muamalat Indonesia, Buku Pedoman Produk Qardhul Hasan Tahun 2010.

http://www. mui.or.id/index.php? option=com content\&view= article\&id=57\&Itemid=83, diakses pada tanggal 12 Pebruari 2012.

Iwan Agustiawan, Sekretaris BMM, Wawancara tanggal 12 Januari 2012. 